\title{
Comparative Effects of Individual and Consortia Plant Growth Promoting Bacteria on Physiological and Enzymatic Mechanisms to Confer Drought Tolerance in Maize (Zea mays L.)
}

\author{
Muhammad Saleem $^{1} \cdot$ Fahim Nawaz ${ }^{1,2}$ (D) $\cdot$ Muhammad Baqir Hussain $^{3} \cdot$ Rao Muhammad Ikram $^{1}$
}

Received: 17 June 2021 / Accepted: 13 September 2021 / Published online: 28 September 2021

(c) The Author(s) 2021

\begin{abstract}
Mitigation strategies based on plant-microbe interactions to increase the performance of plants under water-deficit conditions are well documented. However, little is known about a suitable consortium of bacterial inoculants and underlying physiological and enzymatic events to improve drought tolerance in maize. We performed laboratory and pot experiments to understand the synergistic interactions among plant growth-promoting bacteria to alleviate the drought-induced damages in maize. Initially, ten bacterial strains were evaluated for their osmotic stress tolerance capacity by growing them in a media containing $0,10,20$, and $30 \%$ polyethylene glycol (PEG-6000). Also, the seeds of a drought tolerant (NK-6654) and sensitive (SD-626) maize cultivar were inoculated with these bacterial strains in the first pot experiment to determine their effects on the growth and physiological processes. Later, in the second pot experiment, the best performing inoculants were selected to study the individual and synergistic effects of bacterial inoculation to confer drought tolerance in maize. Our findings showed that the inoculation with tolerant strains resulted in higher photosynthetic activity (25-39\%), maintenance of leaf water status (14-18\%) and pigments (27-32\%), and stimulation of antioxidant machinery (28-38\%) than no inoculation in water-stressed maize seedlings. Moreover, the treatment with bacteria consortia further stimulated the drought protective mechanisms and resulted in higher efficiency of photosynthetic (47-61\%) and antioxidant systems (42-62\%) than the individual inoculants under water-deficit conditions. We conclude that the inoculation with microbial consortia regulates water uptake, photosynthetic performance, and stress metabolites to minimize drought-induced damages in maize.
\end{abstract}

Keywords Bacterial inoculants $\cdot$ Microbial consortia $\cdot$ Drought $\cdot$ Photosynthetic activity $\cdot$ Antioxidant machinery $\cdot$ Zea mays

\section{Introduction}

Improving crop productivity to feed the burgeoning global population is a complex and challenging issue (Buono 2020). Moreover, the recurrent occurrence of climatic extremes has made it more difficult to obtain optimum yields in important food crops including maize. Increasing climate change, poor

Fahim Nawaz

fahim5382@gmail.com; fahim.nawaz@uni-hohenheim.de

1 Department of Agronomy, MNS-University of Agriculture, Multan, Pakistan

2 Department of Nutritional Crop Physiology (340 h), University of Hohenheim, 70599 Stuttgart, Germany

3 Department of Soil and Environmental Sciences, MNS-University of Agriculture, Multan, Pakistan management of water resources, unavailability of water at critical growth stages, and unfit soil conditions are among the major factors responsible for the poor performance of agriculture sector in recent decades. Consequently, the increased volatility in global cereal markets during the past decades has generated uncertainty among farmers and reduced food access to poor consumers (Tigchelaar et al. 2018). The crop yield variability is likely to increase in the future due to the reduced availability of water for agriculture, which would severely compromise food access and adversely affect the food security for people living in the developing countries (Luhunga 2017). It is estimated that the water deficit stress has caused a loss of more than 1820 million $\mathrm{Mg}$ to cereal (wheat, rice, and maize) production during the past four decades (Lesk et al. 2016).

Maize is considered to be the most negatively affected in several assessments of climate change impacts on crops 
(Deryng et al. 2014; Tebaldi and Lobell 2018; Zampieri et al. 2019). Though the maize originated from tropics but the low water availability makes it difficult for the plants to survive (Daryanto et al. 2016). During the maize growth cycle, water shortage may result in the inhibition of photosynthesis, thus also reducing the availability of nutrients to generative organs (Zipper et al. 2016). The declined activity of photosynthetic apparatus primarily by stomatal closure, degradation of chlorophyll, and alterations in the functioning of key metabolic enzymes are the major outcomes of drought in maize (Majeed et al. 2018; Usmani et al. 2020). Like most plants facing water shortage, maize plants are able to sustain growth by the increased uptake of water and nutrients and the regulation of stress metabolites such as antioxidative enzymes under arid conditions (Naeem et al. 2018). However, a continuous or prolonged exposure to drought may cause irreversible damage to growth that ultimately affects the grain yield of maize (Karim and Rahman 2015). Breeding for drought tolerant, high-yielding maize genotypes could be one of the solutions to confront the challenges of food security; however, it is a time-consuming and labor-intensive process. Moreover, it also possess ecological risks and the transgenic crops may face little acceptability by the consumers. Therefore, the use of microbial inoculants provides an alternative and economically viable solution to support maize growth under water-deficit conditions.

Microbial stimulants such as mycorrhizal fungi, nitrogen fixing bacteria, and plant growth-promoting (PGP) species/ genera have received great attention as a potential measure to improve plant growth under stressful environmental conditions, including drought (Kumar and Verma 2018; Joshi et al. 2020). These microbes inhabit rhizosphere and make an optimal use of their biological processes to support soil fertility, plant growth, and resource efficiency in both well watered and water deficit environment (Khan et al. 2018). Among different soil-borne microbes, plant growth-promoting bacteria (PGPB) are well known to colonize rhizosphere, and can survive extremely dry conditions (Abolhasani et al. 2010). Application of PGPB alters root architecture and increases the nutrient uptake and water drawing capacity of plants (Kasim et al. 2013). Also, the ability of microbes to protect cellular metabolites and macromolecules by reducing reactive oxygen species (ROS) generation and increasing ROS detoxification (Yang et al. 2020) remains crucial for plant survival under drought stress (Gouda et al. 2018). The bacterial inoculants influence the production of phytohormones (including auxins, gibberellins, abscisic acid, ethylene), solubilization of mineral phosphates, and catabolism of stress signaling molecules such as bacterial 1-aminocyclopropane-1-carboxylate (ACC) deaminase that can affect the physiological mechanisms related to growth and drought tolerance (Ulrich et al. 2019). In addition, PGPB also encourage the drought tolerance ability of host plants by regulating the synthesis of osmolytes, exopolysaccharides (EPS), and stress proteins (Niu et al. 2018). Emerging evidence indicates that the combined application of microbial inoculants could be more beneficial than individual strains to improve drought tolerance in plants (Berg et al. 2020; Kavadia et al. 2020). It is believed that the use of microbial consortia, instead of single seed inoculants, may provide a significant advantage to utilize the complementary properties of various microbial strains differing in stress tolerance (Woo and Pepe 2018).

In this study, we used pre-isolated and pre-characterized bacterial strains, viz. Bacillus sp. MN54, Bacillus cereus Y5, Bacillus subtilis Y16, Bacillus sp. Y14, Pseudomonas fluorescens 1, Pseudomonas fluorescens 2, Flavobacterium, Enterobacter sp., Burkholderia phytofirmans PsJN, and Erwinia rhapontici, obtained from the Institute of Soil and Environmental Sciences, University of Agriculture, Faisalabad, Pakistan. The names of the bacterial strains and their accession numbers are given in Table 1. These strains have been previously characterized for growth-promoting attributes and are well reported to enhance the stress tolerance of plants under various environmental conditions. For instance, B. cereus Y5, B. subtilis Y16, and Bacillus sp. Y14 were reported to exhibit increased ACC-deaminase activity leading to increased salinity tolerance in wheat (Shahzad et al. 2017; Khan et al. 2017). Similar results were reported for $P$. fluorescens $1, P$. fluorescens 2, Flavobacterium, and Enterobacter sp. in maize by Nadeem et al. (2007, 2010). More recently, Yang et al. (2020) provided further evidence regarding the growth-promoting ability of $B$. phytofirmans PsJN in salt-stressed quinoa plants. Although PGPB are commonly applied to promote plant growth and alleviate drought-induced damages, only few studies report the mechanisms responsible for increased plant tolerance to drought. Also, the physiological changes occurring in plants by the combined application of drought tolerant inoculants have yet to be fully elucidated. Therefore, the current study involved successive laboratory and pot experiments with the specific objectives to (i) evaluate the potential of isolated

Table 1 The accession numbers of the bacterial strains used for the experiments

\begin{tabular}{llll}
\hline Sr. No & Name of species & Name of strain & Accession number \\
\hline 1 & Bacillus cereus & Y5 & KM652420 \\
2 & Bacillus sp. MN54 & KS-54 & KT375574 \\
3 & Bacillus sp. & Y14 & KM652421 \\
4 & Bacillus substilis & Y16 & KM652422 \\
5 & Enterobacter sp. & FD17 & KF147850 \\
6 & Pseudomonas fluorescens 1 & PfO & NR103091 \\
7 & Pseudomonas fluorescens 2 & IAM & NR043420 \\
8 & Erwinia rhopantici & DSM 4484 & NR041976 \\
9 & Flavobacterium crocinum & HYNO056 & CP029255 \\
10 & Burkholderia phytofirmans & PsJN & NR 103,337 \\
\hline
\end{tabular}


bacterial strains for drought tolerance, (ii) determine the effects of bacterial strains, differing in their ability to tolerate drought, on growth of water stressed maize seedlings, and (iii) characterize the effectiveness of bacterial consortia to regulate physiological mechanisms associated with improved drought tolerance in maize. We hypothesized that bacterial inoculation influences early maize growth by regulating the activity of photosynthetic apparatus and stimulating antioxidant machinery under water-deficit conditions. Moreover, we also tested the hypothesis that the combined inoculation of bacterial inoculants is more effective than the individual strains to regulate defense mechanisms related to drought tolerance in maize.

\section{Materials and Methods}

\subsection{Laboratory Experiment-Inoculum Preparation and Drought Tolerance Assay}

Sterilized broth media (100 ml) of trypton soya broth (TSB) were prepared for each strain. Each bacterial strain was inoculated on separate media and incubated at $28 \pm 1{ }^{\circ} \mathrm{C}$ and $180 \mathrm{rpm}$ on orbital shaking incubator for $48 \mathrm{~h}$ (NB-205 LF). The culture was cold centrifuged $\left(4^{\circ} \mathrm{C}\right)$ at $4000 \mathrm{rpm}$ for $10 \mathrm{~min}$ to harvest the bacterial cells. The inoculum with the optical density (OD) of 0.5 McFarland units (i.e., 10 cells $\mathrm{ml}$ ) was maintained in sterilized TSB liquid medium using densitometer (Den-1 Densitometer, McFarland, UK). The un-inoculated control medium was maintained to subtract its OD from the OD of the inoculum.

To evaluate the drought tolerance capacity of bacterial strains, a laboratory experiment was conducted in controlled conditions of MNS-University of Agriculture, Multan. The bacterial strains were grown in Erlenmeyer flasks containing $100 \mathrm{ml}$ of Trypton Soya Broth (TSB) media and were incubated for $72 \mathrm{~h}$ in shaking incubator at $28 \pm 1{ }^{\circ} \mathrm{C}$. After 3 days, media was centrifuged to harvest bacterial cells and the uniform cell density $\left(10^{8} \mathrm{cfu} \mathrm{ml}^{-1}\right)$ was maintained. The osmotic stress levels were developed by adding PEG in TSB broth media at 10\%, 20\%, and 30\% (Busse and Bottomley 1989). The osmotic potential of broth media was measured by an osmometer (Wescor, Model 5520) at respective PEG-6000 levels $-0.04,-0.60,-1.46$, and $-2.10 \mathrm{MPa}$ osmotic potentials which were recorded at $0,10,20$, and $30 \%$ PEG in broth media. Prepared inocula $(0.5 \mathrm{ml})$ with uniform cell density $\left(10^{7}\right.$ to $\left.10^{8} \mathrm{cfu} \mathrm{ml}^{-1}\right)$ were inoculated in test tubes having PEG and incubated in shaking incubator for 4 days. The optical density was measured using a spectrophotometer at $600 \mathrm{~nm}$ after 4 days of incubation (Fig. 1). The isolates showing high number of viable cells were designated as more drought tolerant. All bacterial strains were categorized as highly tolerant (Bacillus sp. MN54 and Enterobacter sp.), moderate tolerant (P. fluorescens 1; P. fluorescens 2, B. cereus Y5, B. subtilis Y16, Bacillus sp. Y14, and B. phytofirmans PsJN), and sensitive (Flavobacterium and Erwinia rhapontici) to drought on the basis of increase in growth under osmotic stress (Fig. 1), and later used for further experiments.
Fig. 1 Effect of different concentrations $(-0.04,-0.6,-1.4$ $6,-2.10 \mathrm{MPa})$ of polyethylene glycol (PEG-6000)-induced osmotic stress on growth (measured as optical density) of isolated bacterial species

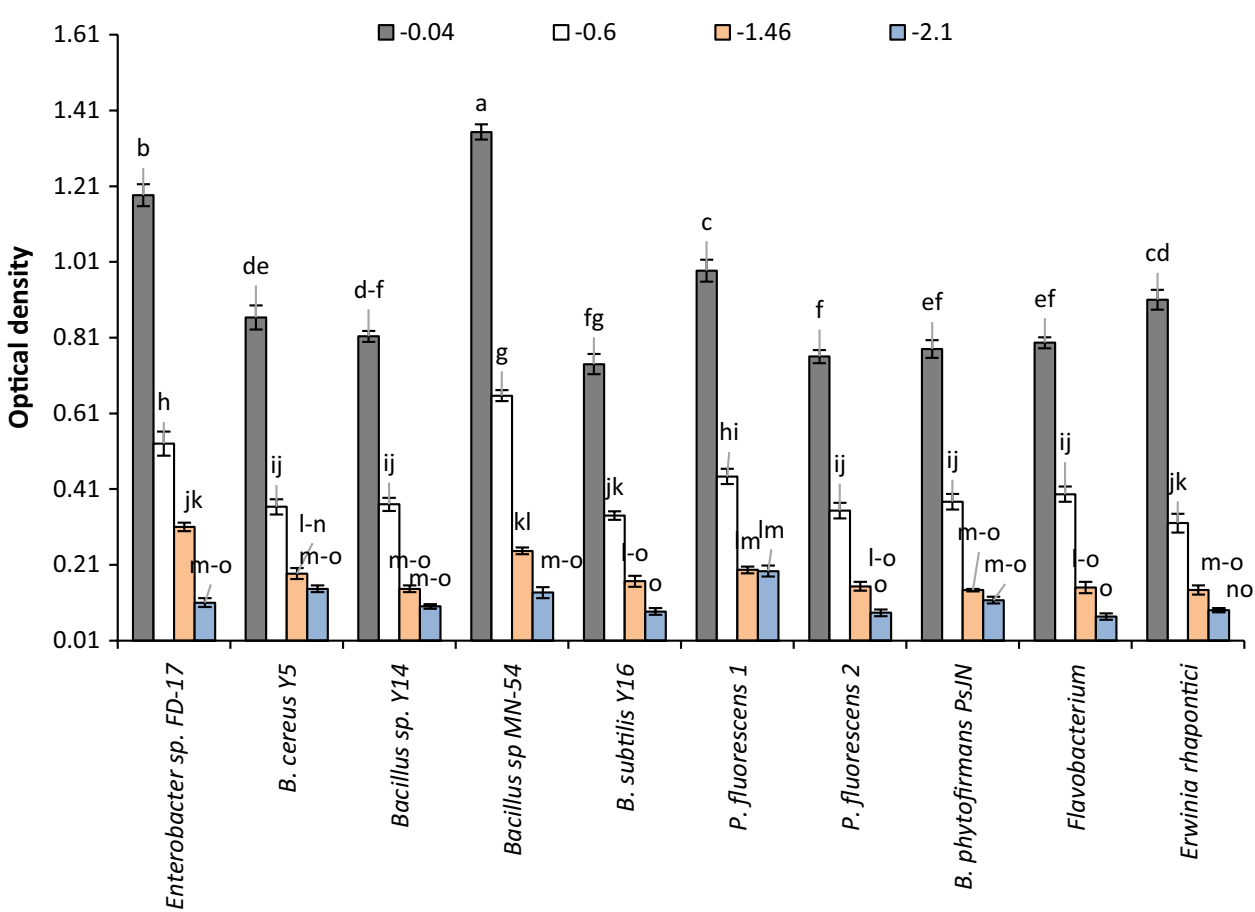

Bacterial strains 


\subsection{Pot Experiment-I}

This study was conducted in a wire house under semicontrolled conditions of natural light $(14 \mathrm{~h}$ day light, $28{ }^{\circ} \mathrm{C} / 16{ }^{\circ} \mathrm{C}$ day/night temperature, and $60 \%$ relative humidity). Ten bacterial strains mentioned earlier, differing in their ability for drought tolerance, were individually tested for their effects on maize physiological mechanisms under well watered (100\% field capacity) and drought stress (60\% field capacity) conditions. The drought levels were defined in terms of field capacity after measuring the water retention capacity of soil (used in the experiment). The amount of water to be added in the soil to achieve moisture contents of $100 \%$ and $60 \%$ field capacity was calculated as reported by Imran et al. (2014).

A pilot study was also done to evaluate the response of available indigenous maize germplasm to drought stress and the most drought tolerant (NK-6654) and sensitive (SD-626) maize hybrids were selected for this experiment on the basis of increase in germination and biomass accumulation under drought stress conditions (data presented in supplementary tables 1 and 2). The randomly selected, healthy, and pure seeds of both maize hybrids were surface sterilized by dipping them in $70 \%$ ethanol ( $2 \mathrm{~min}$ ) and 5\% sodium hypochlorite $(\mathrm{NaOCl})$ solution $(5 \mathrm{~min})$, and washed (2-3 times) using autoclaved deionized water (DI). Seed inoculation with each strain was done by coating a slurry of clay, peat, $10 \%$ sugar solution, and respective bacterial culture at 1:2:1:1 ratio. Peat was calculated on weight-to-weight (w/w) basis with seed as 1:1.25. The un-inoculated control was maintained using slurry prepared by mixing sterilized TSB broth with other constituents (peat, clay, sugar solution). Both inoculated and un-inoculated seeds were sown in pots $(45 \times 35 \mathrm{~cm} ; 10 \mathrm{~kg}$ capacity) filled with a mixture of $08 \mathrm{~kg}$ clayey loam soil and sand $(3: 1 \mathrm{w} / \mathrm{w})$ having electrical conductivity (ECe) 4.55 $\mathrm{mS} \mathrm{cm}{ }^{-1}, \mathrm{pH} 7.9$, organic matter percentage 0.70 , saturation percentage 40 , available nitrogen $(\mathrm{N}) 98 \mathrm{mg} \mathrm{kg}^{-1}$, phosphorous (P) $7.32 \mathrm{mg} \mathrm{kg}^{-1}$, potassium (K) $150 \mathrm{mg} \mathrm{kg}^{-1}$, zinc (Zn) $1.09 \mathrm{mg} \mathrm{kg}^{-1}$, copper $(\mathrm{Cu}) 0.27 \mathrm{mg} \mathrm{kg}^{-1}$, iron $(\mathrm{Fe})$ $2.84 \mathrm{mg} \mathrm{kg}^{-1}$, manganese (Mn) $1.92 \mathrm{mg} \mathrm{kg}^{-1}$, and boron (B) $0.11 \mathrm{mg} \mathrm{kg}^{-1}$. Recommended NPK were applied in the form of urea, DAP, and $\mathrm{K}_{2} \mathrm{O}$ respectively as reported by Usmani et al. (2020), and drought levels were maintained gravimetrically. After 35 days of emergence (V10, cob development stage), the data was recorded for gaseous exchange attributes from uppermost, fully expanded young leaves. Later, the fresh leaf samples were collected for water status, pigments, and enzymatic assays following standard procedures. The resulting data was used to identify the three best performing bacterial strains, which were selected for next experiment for their individual and combined effects on the growth of hybrid maize under water-deficit conditions.

\subsection{Pot Experiment-II}

The experimental conditions and materials were the same as mentioned in pot experiment-I. The PGPB inoculants, viz. Bacillus sp. MN-54 (T1), Enterobacter sp. FD-17 (T2), and $P$. fluorescens 1 (T3), were selected on the basis of increase in biomass through regulation of various physiological and enzymatic processes in maize hybrids under drought stress (pot experiment-I). In the second experiment, the individual and combined inoculants, i.e., MN54+P. fluorescens 1 (T4), MN-54+FD-17 (T5), P. fluorescens 1+FD-17 (T6), and MN54+P. fluorescens $1+$ FD-17 (T7) of these strains, were used. The multi-strain inoculants/consortia were made by mixing fresh inocula of each strain prepared in TSB broth in equal proportion. Inocula were tuned to uniform cell density $\left(10^{8} \mathrm{cfu} \mathrm{ml}^{-1}\right)$ and inoculated to maize seeds (Gutiérrez-Zamora and Martínez-Romero, 2001). The growth conditions were maintained as described earlier for pot experiment-I. The drought stress levels were maintained at $100 \%$ (well-watered) field capacity for the control treatment, whereas water stressed plants were grown at $60 \%$ field capacity. The maize seedlings were harvested after 35 days (V10, cob development stage) and the biochemical attributes were recorded following standard protocols briefly described in the following subsections.

\subsection{Estimation of Water Status and Pigments}

For the measurement of pigments, fresh leaf sample of $1.0 \mathrm{~g}$ was taken for each treatment, chopped into $0.5 \mathrm{~cm}$ pieces, and then placed for extraction in $10 \mathrm{ml}\left(80 \%\right.$ acetone) at $4{ }^{\circ} \mathrm{C}$ for over-night for estimation of chlorophyll a $\left(\mathrm{Chl}_{\mathrm{a}}\right)$, chlorophyll $\mathrm{b}$ $\left(\mathrm{Chl}_{\mathrm{b}}\right)$, and carotenoid (CAR) contents according to the methods of Arnon (1949) and Davies (1976). The following formulae were used to calculate $\mathrm{Chl}_{\mathrm{a}}, \mathrm{Chl}_{\mathrm{b}}$, and CAR contents after measuring the absorbance of supernatant on a spectrophotometer (CECIL, CE7400S) at 663, 645, and $480 \mathrm{~nm}$.

$$
\begin{aligned}
& \text { Chla }\left(\mathrm{mgg}^{-1} \mathrm{FW}\right)=[12.7(\text { OD663 })-2.69(\text { OD645) })] \times V / 1000 \times W \\
& \text { Chlb }\left(\mathrm{mgg}^{-1} \mathrm{FW}\right)=[22.9(\text { OD } 645)-4.68(\text { OD } 663)] \times V / 1000 \times W \\
& \text { CAR }\left(\mathrm{\mu gg}^{-1} \mathrm{FW}\right)=A_{\text {car }} / E_{\text {max }} \times 100
\end{aligned}
$$

where $\mathrm{V}$ is the volume of sample extract and $\mathrm{W}$ is the weight of the sample and $A_{c a r}=(O D 480)+0.114$ (OD663)-0.638 (OD645); $\mathrm{E}_{\max }=2500$.

\subsection{Measurement of Gas Exchange Characteristics}

The gas exchange characteristics such as the net photosynthetic rate $(A)$, transpiration rate $(E)$, stomatal conductance $\left(g_{s}\right)$, and intercellular $\mathrm{CO}_{2}$ concentration $\left(C_{i}\right)$ 
were measured on the upper fully expanded leaves with a CIRAS-3 portable open-flow gas exchange (PP systems, Amesbury, USA) and these parameters were taken in early hours of morning from 9.00 to $11.00 \mathrm{am}$. The chamber was adjusted to $100 \mathrm{ml} \bullet \mathrm{min}^{-1} \mathrm{ml}$ airflow rate, $1200 \mu \mathrm{mol} \cdot \mathrm{m}^{-2} \cdot \mathrm{s}^{-1}$ density of photosynthetic photon flux density, $390 \pm 5 \mu \mathrm{mol} \cdot \mathrm{mol}^{-1} \mathrm{CO}_{2}$ concentration rate, and $99.9 \mathrm{kpa}$ atmospheric pressure.

\subsection{Analysis of Enzymatic Antioxidants}

The leaf samples $(0.5 \mathrm{~g})$ were homologized in mortar and pestle in medium containing $5 \mathrm{ml}$ extraction buffer $(50 \mathrm{mM}$ $\mathrm{Na}_{2} \mathrm{HPO}_{4}$ pH 7.0 and $1 \mathrm{mM}$ dithiothreitol). The sample mixture was then centrifuged $(20,000 \mathrm{~g} 15 \mathrm{~min})$ at $4{ }^{\circ} \mathrm{C}$, and then used for enzyme assays.

The enzymatic activity of catalase (CAT) was analyzed according to the method of Aebi (1984). After degradation of $1 \mathrm{M}$ hydrogen peroxide $\left(\mathrm{H}_{2} \mathrm{O}_{2}\right)$, enzyme extract (EE, $\left.200 \mu \mathrm{l}\right)$ was added in reaction mixture (RM, $1.8 \mathrm{ml})$ which contained $\mathrm{H}_{2} \mathrm{O}_{2}(30 \mathrm{mM})$ and K-P-buffer $(50 \mathrm{mM})$ at $7.0 \mathrm{pH}$. The decline in $\mathrm{H}_{2} \mathrm{O}_{2}$ was followed as a reduction in optical density at $240 \mathrm{~nm}$.

The superoxide dismutase (SOD) activity was investigated following Van Rossum et al. (1997) by measuring the enzymatic potential to obstacle photo-chemical decrease in nitroblue tetrazolium chloride (NBT). One SOD unit was defined as the quantity of enzyme required to inhibit $50 \%$ photo reduction of the NBT in comparison to control (tubes containing no EE).

The GPX activity was assayed as described by Urbanek et al. (1991). Two-milliliter reaction mixture was prepared by mixing K-P buffer $(50 \mathrm{Mm})$ at $6.8 \mathrm{pH}, \mathrm{H}_{2} \mathrm{O}_{2}(20 \mathrm{Mm})$, and guaiacol $(20 \mathrm{Mm})$ and $25 \mu \mathrm{M}$ was added in this RM. It was incubated for $10 \mathrm{~min}$ and then reaction was stopped by mixing $0.5 \mathrm{mM}$ of $\mathrm{H}_{2} \mathrm{SO}_{4}(5 \%)$ and at $480 \mathrm{~nm}$ absorbance was noted.

\subsection{Statistical Analysis}

All experiments were performed in a completely randomized design with three replications. The computer software STATISTIX 8.1 was used for the statistical analyses of the collected data. The analysis of variance technique at 5\% probability level was employed to compare the treatment means with post hoc Tukey test.

\section{Results}

\subsection{Tolerance of Bacterial Strains to Osmotic Stress}

The bacterial strains were grown in PEG-supplemented growth medium to evaluate their potential to tolerate osmotic stress. All strains were able to grow at different concentrations of PEG ranging from -0.04 to $-2.10 \mathrm{MPa}$ (Fig. 1). The response of bacterial strains varied at different concentrations and the negative effects of PEGinduced osmotic stress on growth increased by increasing PEG concentrations in comparison to control without the osmotic agent ( $-0.04 \mathrm{MPa})$. Strain MN-54 showed the best performance and exhibited the smallest decline of $10 \%$, $65 \%$, and $81 \%$ in growth at different PEG-concentrations of $-0.60,-1.46$, and $-2.10 \mathrm{MPa}$, respectively, with respect to control. Similarly, a decline of $37 \%, 53 \%$, and $87 \%$ in growth was observed for strain Enterobacter at different PEG concentrations of $-0.60,-1.46$, and $-2.10 \mathrm{MPa}$, respectively (Fig. 1). The highest decrease in growth $(91 \%)$ was observed for Flavobacterium and E. rhapontici at PEG concentration of $-2.10 \mathrm{MPa}$, whereas the other strains, viz. Y5, Y14, P. fluorescens 1, P. fluorescens 2, and B. phytofirmans, showed better osmotic tolerance and exhibited $77-80 \%(-1.46 \mathrm{MPa})$ and $82-88 \%$ decline $(-2.10 \mathrm{MPa})$ as compared to control (Fig. 1). Taken together, on the basis of these results, the bacterial strains were ranked as the highly tolerant (MN-54 and Enterobacter), moderate tolerant (Y5, Y14, P. fluorescens 1, P. fluorescens 2, and B. phytofirmans), and sensitive (Flavobacterium and E. rhapontici) to osmotic stress for further studies.

\subsection{Protective Effects of PGPB Strains Against Drought}

The first pot experiment evaluated the effects of bacterial inoculation on biomass, physiological processes (water status, pigments, gas exchange characteristics), and biochemical events (activity of enzymatic antioxidants) of drought tolerant (NK-6654) and sensitive (SD-626) maize hybrids subjected to water stress conditions.

Drought stress negatively affected $(P<0.01)$ the biomass of both maize hybrids (Suppl. Table 3) and caused a significant reduction of $22 \%, 29 \%, 49 \%, 21 \%, 39 \%$, and $22 \%$ in shoot length (SL), root length (SL), shoot fresh weight (SFW), shoot dry weight (SDW), root fresh weight (RFW), and root dry weight (RDW), respectively, as compared to well-watered control. The maize hybrid NK-6654 maintained significantly $(P<0.01)$ higher SL $(13 \%)$, RL (19\%), SFW (20\%), RFW (10\%), SDW (13\%), and RDW (13\%) than SD-626 (Suppl. Table 3). Among bacterial strains, MN-54 resulted in the highest SL (23\%), RL (46\%), SFW (40\%), RFW (52\%), SDW (30\%), and RDW (38\%), statistically related to the biomass of seedlings inoculated with Enterobacter, with respect to no inoculation (control) under drought stress conditions. Also, the inoculation of maize hybrids with $P$. fluorescens 1 induced a considerable $(P<0.01)$ increase in growth attributes, whereas other 
strains exhibited very low or no significant increase in these attributes as compared to control under water-deficit conditions (Suppl. Table 3).

Leaf relative water content (RWC) was determined to estimate the water status of maize seedlings, which was found significantly $(P<0.01)$ lower $(15 \%)$ in water stressed than normal (well-watered) seedlings (Suppl. Table 3). Also, drought stress considerably reduced the photosynthetic pigments as water stressed maize seedlings exhibited 35\%, 22\%, and $29 \%$ lower chlorophyll a $\left(\mathrm{Chl}_{\mathrm{a}}\right)$, chlorophyll b $\left(\mathrm{Chl}_{\mathrm{b}}\right)$, and carotenoids (CAR) content than the normal ones (Suppl. Table 3). A marked variation $(P<0.01)$ was also observed between the maize hybrids as NK-6654 maintained higher RWC (7\%), $\mathrm{Chl}_{\mathrm{a}}(13 \%), \mathrm{Chl}_{\mathrm{b}}(12 \%)$, and CAR (10\%) than SD-626 under drought stress conditions. The maize seedlings inoculated with strain MN-54 maintained the highest leaf RWC (18\%) statistically related to inoculation with Enterobacter (16\%), P. fluorescens 1 (14\%), P. fluorescens 2 (12\%), and Y5 (10\%) under water limitations (Suppl. Table 3). Similar trend was observed for photosynthetic pigments as inoculation with strain MN-54 gave the highest increase in $\mathrm{Chl}_{\mathrm{a}}(32 \%), \mathrm{Chl}_{\mathrm{b}}(22 \%)$, and CAR (27\%) contents, while no significant increase was recorded in seedlings inoculated with E. rhapontici, Flavobacterium, and B. phytofirmans with respect to un-inoculated control under drought stress (Suppl. Table 3).

Compared with well-watered conditions, drought stress markedly $(P<0.01)$ reduced the photosynthetic rate $(A)$, transpiration $(E)$, stomatal conductance $\left(g_{s}\right)$, and intercellular $\mathrm{CO}_{2}$ concentration $\left(C_{i}\right)$ of maize hybrids by $31 \%, 10 \%, 50 \%$, and $26 \%$, respectively (Suppl. Table 4). The maize hybrid NK-6654 exhibited significantly higher $A(18 \%), g_{s}(26 \%)$, and $C_{i}(8 \%)$ than SD-626, which maintained higher $E(13 \%)$ under water-deficit conditions. A significant interactive effect $(P<0.01)$ between maize hybrids $(\mathrm{H})$ and the inoculation treatments (T) showed that the strain MN-54 gave the highest increment in $A(38 \%)$, and $g_{s}(39 \%)$ in water stressed NK-6654 seedlings, statistically at par with Enterobacter and P. fluorescens 1 (Suppl. Table 4). On the contrary, these strains exhibited the lowest $E$, which was found maximum in SD-626 seedlings inoculated with E. rhapontici, and statistically related to the inoculation of SD-626 with Flavobacterium, B. phytofirmans, and no inoculation (control) under drought stress conditions (Suppl. Table 4). Similarly, the maize seedlings inoculated with MN-54 maintained the highest $C_{i}(25 \%)$ with respect to un-inoculated control under water-deficit conditions (Suppl. Table 4).

As expected, the enzymatic activity of antioxidants was considerably $(P<0.01)$ higher in the water stressed than wellwatered maize seedlings (Suppl. Table 4). In comparison to well-watered conditions, drought stress significantly stimulated the activity of catalase (CAT), superoxide dismutase (SOD), and guaiacol peroxidase (GPX) by $34 \%, 59 \%$, and
$56 \%$, respectively (Suppl. Table 4). A marked variation was also observed between maize hybrids as drought tolerant NK-6654 exhibited significantly higher CAT (6\%), SOD $(14 \%)$, and GPX (11\%) activity than sensitive SD-626. The strains MN-54, Enterobacter, P. fluorescens 1, and Y5 further enhanced $(P<0.01)$ the activity of CAT by $37 \%, 33 \%, 31 \%$, and $28 \%$ with respect to un-inoculated control under drought stress. Similarly, the highest increment in SOD (38\%) and GPX activity (37\%) was recorded in seedlings inoculated with MN-54 than no inoculation under water-deficit conditions (Suppl. Table 4).

\subsection{Synergistic Effects of PGPB Inoculants and Consortium Against Drought}

The best performing bacterial strains, viz. Bacillus sp. MN-54 (T1), Enterobacter (T2), and P. fluorescens 1 (T3), were selected for the second experiment to determine the individual and combined contributions, i.e., MN54+P. fluorescens 1 (T4), MN-54+Enterobacter (T5), P. fluorescens $1+$ Enterobacter $(\mathrm{T} 6)$, and MN54 + P. fluorescens $1+$ Enterobacter (T7) of these strains to the drought-protective effects at the physiological levels.

The biomass of maize seedlings was significantly $(P<0.01)$ affected by drought stress (Table 2$)$. Our results showed a marked reduction of $48 \%, 55 \%, 53 \%, 44 \%, 56 \%$, and $35 \%$ in SL, RL, SFW, RFW, SDW, and RDW, respectively, in the water stressed than well-watered seedlings (Table 2). The inoculation with bacterial strains, individual, or combined as a consortium, considerably increased the biomass of maize seedlings under water-deficit conditions (Table 2). However, the inoculation of NK-6654 with bacterial consortium $\mathrm{MN}-54+$ Enterobacter (T5) gave the highest increase in SL (44\%), RL (52\%), SFW (36\%), RFW (40\%), SDW (44\%), and RDW (38\%) with respect to un-inoculated control under drought stress. Moreover, a marked increment of $42 \%, 50 \%, 31 \%, 30 \%, 37 \%$, and $37 \%$ in SL, RL, SFW, RFW, SDW, and RDW, respectively, was observed by the combined application of inoculants MN54 + P. fluorescens $1+$ Enterobacter (T7) than no inoculation under water limitations. Also, compared with sensitive maize hybrid (SD-626), NK-6654 (drought tolerant) exhibited significantly higher SL (11\%), RL (15\%), SFW (14\%), RFW (9\%), SDW (9\%), and RDW (7\%) (Table 2).

Drought-induced reductions on the leaf RWC (36\%) and photosynthetic pigments, viz. $\mathrm{Chl}_{\mathrm{a}}(48 \%), \mathrm{Chl}_{\mathrm{b}}(45 \%)$, and CAR (36\%), were significantly ameliorated by the inoculation of maize seedlings with bacterial strains (Table 2). It was observed that the consortium inoculants were more effective in the maintenance of leaf RWC and pigments as compared to the inoculation of individual strains under drought stress (Table 2). In comparison to un-inoculated control, the highest 


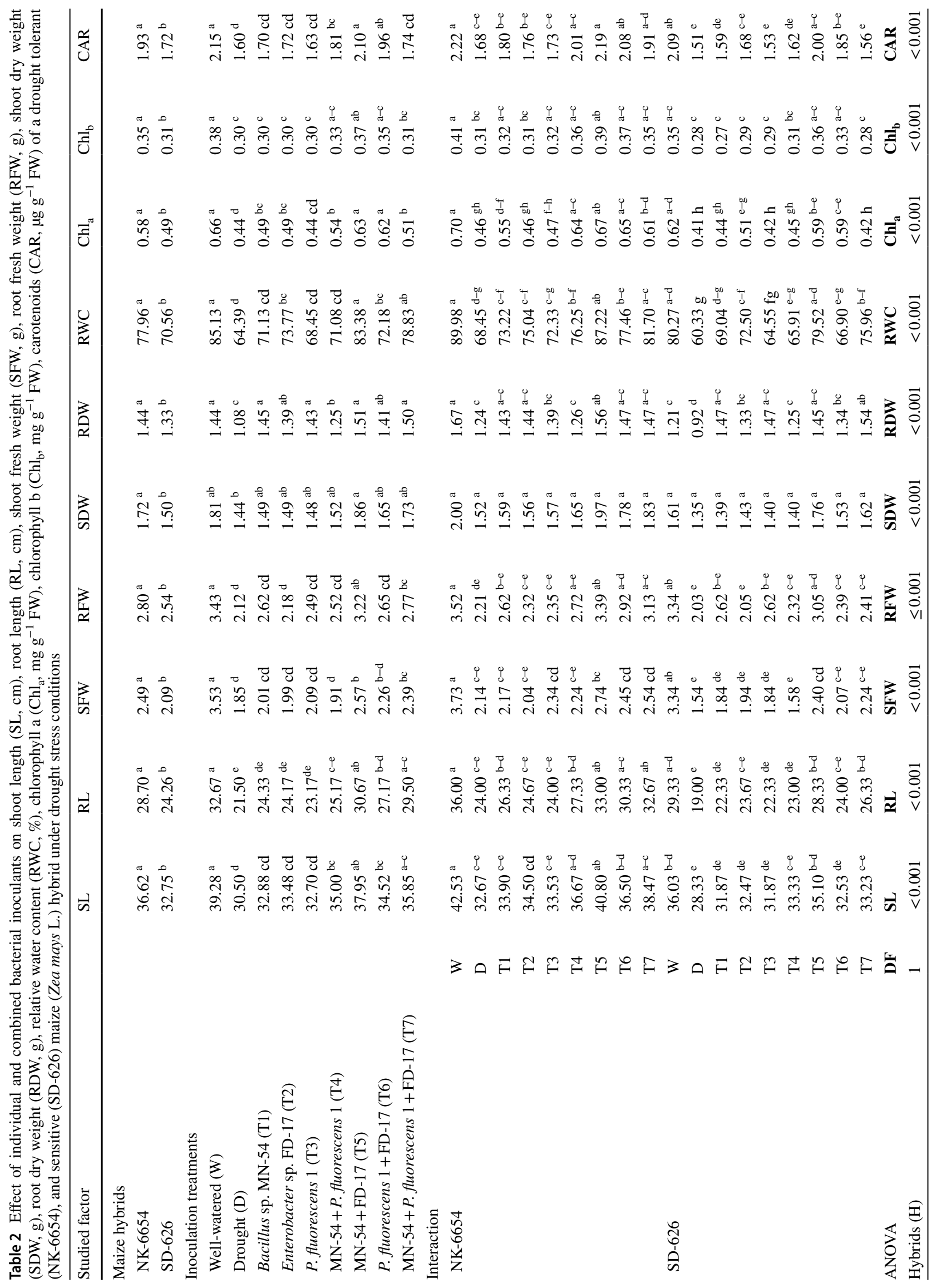




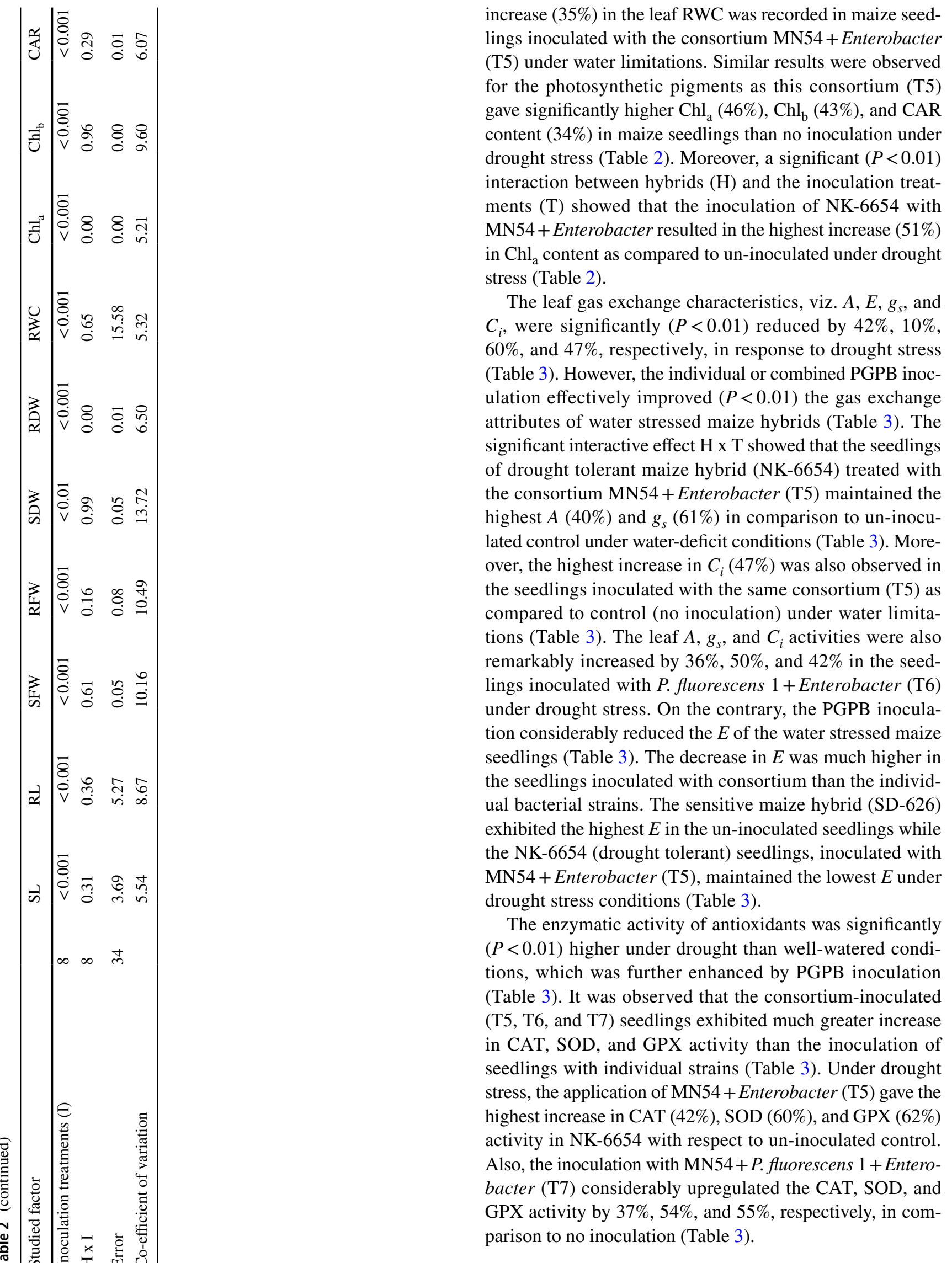


Table 3 Effect of individual and combined bacterial inoculants on photosynthetic rate $\left(A, \mu \mathrm{mol} \mathrm{CO}_{2} \mathrm{~m}^{-2} \mathrm{~s}^{-1}\right)$, transpiration rate $(E$, mmol $\left.\mathrm{H}_{2} \mathrm{O} \mathrm{m}^{-2} \mathrm{~s}^{-1}\right)$, stomatal conductance $\left(g_{s}, \mathrm{mmol} \mathrm{H}_{2} \mathrm{O} \mathrm{m}^{-2} \mathrm{~s}^{-1}\right)$, sub-stomatal conductance $\left(C_{i}, \mu \mathrm{mol} \mathrm{H}_{2} \mathrm{O} \mathrm{m}^{-2} \mathrm{~s}^{-1}\right)$, and the enzymatic activity of catalase (CAT, $\mu \mathrm{mol} \mathrm{H}_{2} \mathrm{O}_{2} \mathrm{~m}^{-2} \mathrm{~s}^{-1}$ ), superoxide dismutase
(SOD, Units $\mathrm{min}^{-1} \mathrm{mg}^{-1}$ protein), and guaiacol peroxidase (GPX,

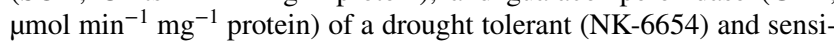
tive (SD-626) maize (Zea mays L.) hybrid under drought stress conditions

\begin{tabular}{|c|c|c|c|c|c|c|c|c|}
\hline Studied factor & & $A$ & $E$ & $g_{s}$ & $C_{i}$ & CAT & SOD & GPX \\
\hline \multicolumn{9}{|l|}{ Maize hybrids } \\
\hline NK-6654 & & $4.12^{\mathrm{a}}$ & $1.89^{\mathrm{b}}$ & $69.00^{\mathrm{a}}$ & $71.04^{\mathrm{a}}$ & $238.56^{\mathrm{a}}$ & $46.55^{\mathrm{a}}$ & $52.74^{\mathrm{a}}$ \\
\hline SD-626 & & $3.39^{b}$ & $2.11^{\mathrm{a}}$ & $57.11^{\mathrm{b}}$ & $67.18^{b}$ & $226.56^{b}$ & $39.04^{b}$ & $47.96^{\mathrm{b}}$ \\
\hline \multicolumn{9}{|l|}{ Inoculation treatments } \\
\hline Well-watered (W) & & $4.55^{\mathrm{a}}$ & $2.82^{\mathrm{a}}$ & $85.33^{\mathrm{a}}$ & $79.33^{a}$ & $145.00^{\mathrm{e}}$ & $15.50^{\mathrm{f}}$ & $18.67^{\mathrm{f}}$ \\
\hline Drought (D) & & $3.15^{c}$ & $2.38^{b}$ & $53.50^{\mathrm{d}}$ & $62.17 \mathrm{~cd}$ & $205.00^{\mathrm{d}}$ & $36.00^{\mathrm{e}}$ & $44.50^{\mathrm{e}}$ \\
\hline Bacillus sp. MN-54 (T1) & & $3.61^{\mathrm{bc}}$ & $2.29^{b}$ & $54.00^{d}$ & $65.17^{\mathrm{b}-\mathrm{d}}$ & $219.17 \mathrm{~cd}$ & $39.50^{\mathrm{de}}$ & $49.67^{\text {de }}$ \\
\hline Enterobacter sp. FD-17 (T2) & & $3.28^{\mathrm{c}}$ & $2.01^{\mathrm{c}}$ & $58.83^{\mathrm{d}}$ & $64.83^{\mathrm{b}-\mathrm{d}}$ & $234.00^{\mathrm{b}-\mathrm{d}}$ & $44.33 \mathrm{~cd}$ & $51.33 \mathrm{~cd}$ \\
\hline P. fluorescens 1 (T3) & & $3.71^{b c}$ & $2.34^{\mathrm{b}}$ & $54.67^{\mathrm{d}}$ & $61.67^{\mathrm{d}}$ & $218.50 \mathrm{~cd}$ & $38.83 \mathrm{~cd}$ & $54.00^{\mathrm{b}-\mathrm{d}}$ \\
\hline MN-54+P. fluorescens 1 (T4) & & $3.29^{c}$ & $1.75^{\mathrm{d}}$ & $59.17^{\mathrm{d}}$ & $66.67^{\mathrm{b}-\mathrm{d}}$ & $255.50^{\mathrm{a}-\mathrm{c}}$ & $50.33^{\mathrm{bc}}$ & $52.17^{\mathrm{b}-\mathrm{d}}$ \\
\hline MN-54 + FD-17 (T5) & & $4.55^{\mathrm{a}}$ & $1.23^{\mathrm{e}}$ & $76.67^{\mathrm{b}}$ & $79.50^{\mathrm{a}}$ & $292.83^{\mathrm{a}}$ & $58.00^{\mathrm{a}}$ & $68.33^{\mathrm{a}}$ \\
\hline P. fluorescens 1+FD-17 (T6) & & $4.17^{\mathrm{ab}}$ & $1.52^{\mathrm{d}}$ & $68.00^{\mathrm{c}}$ & $72.83^{\mathrm{ab}}$ & $253.67^{\mathrm{a}-\mathrm{c}}$ & $50.67^{\mathrm{b}}$ & $56.33^{\mathrm{bc}}$ \\
\hline $\mathrm{MN}-54+$ P. fluorescens $1+\mathrm{FD}-17$ (T7) & & $3.49^{\mathrm{c}}$ & $1.66^{\mathrm{d}}$ & $57.33^{\mathrm{d}}$ & $69.83^{\mathrm{bc}}$ & $269.50^{\mathrm{ab}}$ & $52.00^{\mathrm{ab}}$ & $58.17^{\mathrm{b}}$ \\
\hline \multicolumn{9}{|l|}{ Interaction } \\
\hline \multirow[t]{9}{*}{ NK-6654 } & $\mathrm{W}$ & $4.87^{\mathrm{a}}$ & $2.76^{\mathrm{ab}}$ & $90.33^{\mathrm{ab}}$ & $83.00^{\mathrm{a}}$ & $146.00^{\mathrm{f}}$ & $15.67^{\mathrm{i}}$ & $19.67 \mathrm{~h}$ \\
\hline & $\mathrm{D}$ & $3.42 \mathrm{~cd}$ & $2.25 \mathrm{~cd}$ & $57.33^{\mathrm{d}-\mathrm{f}}$ & $63.67^{\mathrm{b}-\mathrm{d}}$ & $207.00^{\text {ef }}$ & $38.67^{\mathrm{f}-\mathrm{h}}$ & $45.00 \mathrm{fg}$ \\
\hline & $\mathrm{T} 1$ & $4.31^{\mathrm{a}-\mathrm{c}}$ & $2.12 \mathrm{de}$ & $58.33^{\mathrm{d}-\mathrm{f}}$ & $65.33^{b-d}$ & $219.33^{\mathrm{c}-\mathrm{e}}$ & $40.67^{\mathrm{e}-\mathrm{h}}$ & $50.00^{\mathrm{e}-\mathrm{g}}$ \\
\hline & $\mathrm{T} 2$ & $3.42 \mathrm{~cd}$ & $1.66 \mathrm{fg}$ & $66.33 \mathrm{~cd}$ & $68.33^{b-d}$ & $243.00^{\mathrm{a}-\mathrm{e}}$ & $48.67^{\mathrm{c}-\mathrm{e}}$ & $48.00^{\mathrm{e}-\mathrm{g}}$ \\
\hline & $\mathrm{T} 3$ & $4.37^{\mathrm{ab}}$ & $2.17^{\mathrm{c}-\mathrm{e}}$ & $56.00^{\mathrm{d}-\mathrm{f}}$ & $63.00 \mathrm{~cd}$ & $226.00^{\mathrm{b}-\mathrm{e}}$ & $43.00^{\mathrm{d}-\mathrm{h}}$ & $61.00^{b c}$ \\
\hline & $\mathrm{T} 4$ & $3.67^{b-d}$ & $1.82^{\text {ef }}$ & $64.00^{\mathrm{de}}$ & $68.33^{b-d}$ & $259.00^{\mathrm{a}-\mathrm{e}}$ & $54.67^{\mathrm{a}-\mathrm{c}}$ & $53.33^{\mathrm{c}-\mathrm{g}}$ \\
\hline & $\mathrm{T} 5$ & $4.90^{\mathrm{a}}$ & $1.06 \mathrm{~h}$ & $90.67^{\mathrm{a}}$ & $82.33^{a}$ & $298.67^{\mathrm{a}}$ & $63.33^{a}$ & $76.33^{a}$ \\
\hline & T6 & $4.67^{\mathrm{a}}$ & $1.52 \mathrm{fg}$ & $77.67^{b c}$ & $72.67^{\mathrm{a}-\mathrm{d}}$ & $271.00^{\mathrm{a}-\mathrm{d}}$ & $58.67^{\mathrm{ab}}$ & $56.00^{\mathrm{b}-\mathrm{e}}$ \\
\hline & $\mathrm{T} 7$ & $3.49^{b-d}$ & $1.71 \mathrm{fg}$ & $60.33^{\mathrm{d}-\mathrm{f}}$ & $72.67^{\mathrm{a}-\mathrm{d}}$ & $277.00^{\mathrm{a}-\mathrm{c}}$ & $55.67^{\mathrm{a}-\mathrm{c}}$ & $65.33^{b}$ \\
\hline \multirow[t]{9}{*}{ SD-626 } & $\mathrm{W}$ & $4.23^{\mathrm{a}-\mathrm{c}}$ & $2.89^{\mathrm{a}}$ & $80.33^{a b}$ & $75.67^{\mathrm{a}-\mathrm{c}}$ & $144.00^{\mathrm{f}}$ & $15.33^{i}$ & $17.67 \mathrm{~h}$ \\
\hline & $\mathrm{D}$ & $2.88^{\mathrm{d}}$ & $2.52^{\mathrm{a}-\mathrm{c}}$ & $49.67^{\mathrm{f}}$ & $60.67^{d}$ & $203.00^{\text {ef }}$ & $33.33 \mathrm{~h}$ & $44.00 \mathrm{~g}$ \\
\hline & $\mathrm{T} 1$ & $2.92^{\mathrm{d}}$ & $2.47^{b-d}$ & $49.67^{\mathrm{f}}$ & $65.00^{\mathrm{b}-\mathrm{d}}$ & $219.00^{\mathrm{c}-\mathrm{e}}$ & $38.33^{\mathrm{gh}}$ & $49.33^{\mathrm{e}-\mathrm{g}}$ \\
\hline & $\mathrm{T} 2$ & $3.14^{\mathrm{d}}$ & $2.37 \mathrm{~cd}$ & $51.33^{e f}$ & $61.33^{d}$ & $225.00^{\mathrm{b}-\mathrm{e}}$ & $40.00^{\mathrm{e}-\mathrm{h}}$ & $54.67^{\mathrm{c}-\mathrm{f}}$ \\
\hline & $\mathrm{T} 3$ & $3.05^{\mathrm{d}}$ & $2.51^{\mathrm{a}-\mathrm{c}}$ & $53.33^{\mathrm{ef}}$ & $60.33^{d}$ & $211.00^{\mathrm{de}}$ & $34.67 \mathrm{~h}$ & $47.00^{\mathrm{e}-\mathrm{g}}$ \\
\hline & $\mathrm{T} 4$ & $2.90^{\mathrm{d}}$ & $1.68 \mathrm{fg}$ & $54.33^{\mathrm{d}-\mathrm{f}}$ & $65.00^{\mathrm{b}-\mathrm{d}}$ & $252.00^{\mathrm{a}-\mathrm{e}}$ & $46.00^{c-g}$ & $51.00^{\mathrm{d}-\mathrm{g}}$ \\
\hline & $\mathrm{T} 5$ & $4.20^{\mathrm{a}-\mathrm{c}}$ & $1.40^{\mathrm{gh}}$ & $62.67^{\mathrm{de}}$ & $76.67^{\mathrm{ab}}$ & $287.00^{\mathrm{ab}}$ & $52.67^{b-d}$ & $60.33^{b-d}$ \\
\hline & T6 & $3.67^{b-d}$ & $1.53 \mathrm{fg}$ & $58.33^{\mathrm{d}-\mathrm{f}}$ & $73.00^{\mathrm{a}-\mathrm{d}}$ & $236.33^{\mathrm{a}-\mathrm{e}}$ & $42.67^{\mathrm{e}-\mathrm{h}}$ & $56.67^{\mathrm{b}-\mathrm{e}}$ \\
\hline & $\mathrm{T} 7$ & $3.50^{b-d}$ & $1.62 \mathrm{fg}$ & $54.33^{\mathrm{d}-\mathrm{f}}$ & $67.00^{\mathrm{b}-\mathrm{d}}$ & $262.00^{\mathrm{a}-\mathrm{e}}$ & $48.33^{\mathrm{c}-\mathrm{f}}$ & $51.00^{\mathrm{d}-\mathrm{g}}$ \\
\hline ANOVA & DF & $A$ & $E$ & $g_{s}$ & $C_{i}$ & CAT & SOD & GPX \\
\hline Hybrids $(\mathrm{H})$ & 1 & $<0.001$ & $<0.001$ & $<0.001$ & $<0.01$ & $<0.05$ & $<0.001$ & $<0.001$ \\
\hline Inoculation treatments (I) & 8 & $<0.001$ & $<0.001$ & $<0.001$ & $<0.001$ & $<0.001$ & $<0.001$ & $<0.001$ \\
\hline $\mathrm{H} \times \mathrm{I}$ & 8 & $<0.01$ & $<0.001$ & $<0.001$ & 0.75 & 0.92 & $<0.001$ & $<0.001$ \\
\hline Error & 34 & 0.09 & 0.01 & 17.59 & 18.23 & 429.8 & 10.13 & 10.31 \\
\hline Co-efficient of variation & & 8.14 & 6.22 & 6.65 & 6.18 & 8.91 & 7.44 & 6.38 \\
\hline
\end{tabular}

\section{Discussion}

Drought is one of the most destructive climate extremes causing significant losses to maize production globally (Leng 2021). The intermittent occurrence of water deficit stress severely restricts maize growth and yield at regional to global scales (Madadgar et al. 2017). The development of mitigation and adaptation strategies is critical to overcome the uncertainty of maize yield under drought stress. The use of breeding approaches and genetic tools could be a viable and advanced solution to increase stress resistance in crops but they are time consuming and have ethical issues associated with them. Therefore, the utilization of plant growth promoting potential of microbes may offer a sustainable answer to 
meet the challenges of climate change. It is well established that plant growth promoting microbes play a crucial role to ameliorate the negative effects of environmental stress, especially drought (Rubin et al. 2017; Joshi et al. 2020). As the water deficit stress affects the processes of plant growth at physiological, biochemical, and molecular levels ( $\mathrm{Li}$ et al. 2021), the microbe mediated protective mechanisms augment stress tolerance by increasing the lateral root formation and regulating the photosynthetic capacity and enzymatic activity of antioxidants (Shabbir et al. 2019). It is a well-known fact that the inoculation of crop seeds with PGPB strains enhances the water and nutrient availability to facilitate plant growth in dry soils (Ansari et al. 2021). Since the microbes may differ in their ability to endure stress environments, the selection of drought tolerant PGPB is crucial for the efficient stimulation and activation of defense mechanisms in cereals such as wheat and maize (Jochum et al. 2019).

In the present study, we initially screened out the pre-isolated and pre-characterized bacterial strains for their response to PEG-induced osmotic stress (Fig. 1). Osmotic variations influence the physico-chemical and biological potential of soil, which may diminish the number of inoculated bacteria in dry soils (García et al. 2017). The low water availability affects the bacterial growth in the same way as plants suffer from the water deficit stress; hence, the selection of droughtresistant bacteria could be a viable and effective approach to design new inoculants for arid zones. We found that Bacillus sp. MN-54 exhibited the highest growth providing further evidence that Bacillus spp. are important biological tool with the ability to survive adverse environmental conditions (Radhakrishnan et al. 2017). This strain has been widely used in recent studies to increase crop performance under unfavorable climatic conditions, mainly due to its growth promoting traits including the regulation of 1-aminocyclopropane1-carboxylate (ACC) deaminase activity and the synthesis of phytohormones in plants (Samreen et al. 2019; Afzal et al. 2020). Similarly, B. cereus Y5, and B. subtilis Y16, Bacillus sp. Y14 also showed lower decline in growth at different PEG levels as compared to other bacterial strains. Lyngwi and Joshi (2014) suggested that the more effective metabolite production and spore-forming character of Bacillus spp. could make them one of the most effective biofertilizers in the agricultural industry. Our results showed that Enterobacter spp. were also able to maintain high growth under osmotic stress (Fig. 1), thereby ranked as a drought tolerant species. These findings are concurrent with the report of Naveed et al. (2014) who showed that the Enterobacter sp. FD17 could effectively colonize maize in dry soil. Also, Kang et al. (2015) reported the beneficial effects of inoculation with Enterobacter asburiae KE17 in soybean grown in soils contaminated with copper and zinc. The maintenance of growth by bacterial strains P. fluorescens 1, P. fluorescens 2, and B. phytofirmans PsJN at high PEG concentrations (30\%) suggest the potential of these strains to associate with plant roots and improve growth under water-deficit conditions. The ability of $P$. fluorescens and B. phytofirmans PsJN to upregulate ACC deaminase and EPS activity make them effective bioinoculants to enhance crop growth and yield in arid regions (Naveed et al. 2014; Niu et al. 2018). The observed sensitivity of Flavobacterium spp. to osmotic stress is in accordance with the reports of Waśkiewicz and Irzykowska (2014) who suggested that the species of Flavobacterium could be sensitive to salt stress. Also, E. rhapontici is a bacterial plant pathogen that causes seed-borne diseases in pulses and cereals (Hsieh et al. 2010); however, very few or no studies have been conducted on the response of $E$. rhapontici to osmotic stress.

As the response of PGPB strains varied significantly to different concentrations of PEG-6000, we used these strains to inoculate the seeds of two contrasting maize hybrids, viz. NK-6654 (drought tolerant) and SD-626 (sensitive), and evaluated them for their response to water deficit stress. The adverse effects of drought stress were evident on the biomass accumulation and physiological processes of both maize hybrids, which were found significantly higher in uninoculated than inoculated seedlings. The beneficial effects of PGPB on plant growth are associated with the solubilization of plant nutrients, siderophore production, and regulation of key hormones under water deficit stress (Vurukonda et al. 2016; Zafar-ul-Hye et al. 2019). In the present study, the highest increase in the biomass attributes was observed in the seedlings inoculated with the drought tolerant strains, i.e., MN-54 and Enterobacter. These findings are concurrent with the reports of García et al. (2017) who observed that the inoculation of maize seedlings with the osmotic stresstolerant bacteria improves plant growth under water limitations. Joshi et al. (2020) suggested that the negative impacts of drought on plant growth could be alleviated by the inoculation of seeds with Bacillus spp. that can colonize arid soils and improve soil water potential by increasing the aggregate stability. Such positive effects were also evident in the present study, and the observed increment in shoot and root biomass by bacterial inoculation could be related to the increase in RL and the enhanced formation of later roots and root hair that facilitate the uptake of water and nutrients in plants exposed to drought stress (Niu et al. 2018). The growth promoting ability of these bacterial strains was further enhanced by the combined application of selected inoculants (Bacillus sp. MN-54, Enterobacter, and P. fluorescens 1) as bacterial consortia. In recent years, the co-inoculation of bacterial strains in the same plant has been well reported to stimulate crop growth and development compared to the inoculation of individual bacteria (Mpanga et al. 2019; Molina-Romero et al. 2021). The functional associative symbiosis in consortium formulations is the key to achieve the beneficial effects of consortia on inoculated plants (Drogue et al. 2012). Therefore, it is necessary to evaluate the different combinations 
of bacterial inoculants to identify the most effective consortium that could enhance plant resistance to various biotic and abiotic stresses including drought (Molina-Romero et al. 2017). In the present study, the drought-tolerant NK-6654 seedlings maintained higher biomass by the application of bacterial consortia than the individual inoculants (Table 2). The drought tolerance potential of resistant crop varieties is mainly associated to better root architecture for water and minerals uptake compared to the sensitive ones (Canales et al. 2019), which could be further enhanced by the inoculation of maize hybrids with bacterial consortia, also reported by Pereira et al. (2020).

The soil moisture levels directly affect the water status of leaves that ultimately influence the morphology and phenology of plants (Zhou et al. 2021). A favorable leaf water content is critical for carbon gain, signal transduction, and the translocation of photosynthates in plants (Lin et al. 2019). Majeed et al. (2020) suggested that the leaf RWC is an important drought indicator due to its connection with the soil water availability and stress tolerance mechanisms in plants. In the present study, drought stress triggered a marked decline in the leaf RWC of maize seedlings. However, the inoculation of seedlings with the tolerant PGPB strains (Bacillus spp., Enterobacter, B. phytofirmans, P. fluorescens) compensated the drought effects and helped to maintain higher RWC than un-inoculated control under water-deficit conditions (Suppl. Table 3). These findings imply that the PGPB-mediated alterations in root system architecture optimize the use of water and nutrients for growth under water limitations (Araujo et al. 2021). Also, the leaf RWC is directly influenced by the bacterial abscisic acid (ABA) production that induces stomatal closure to maintain high RWC in inoculated seedlings under dry conditions (Castillo et al. 2013). Sandhya et al. (2009) showed that the inoculation of sunflower with Bacillus spp. stimulates EPS production that improves the permeability and aggregate stability of soil to maintain high water potential around plant roots under water-deficit conditions. Moreover, Bacillus spp. regulate the expression of all plasma membrane intrinsic protein (PIP) genes to enhance the hydraulic conductivity of roots under water limitations (Armada et al. 2015). Similar to our results, Naveed et al. (2014) reported a significant increase in the leaf RWC of maize seedlings inoculated with Enterobacter and B. Phytofirmans PsJN as compared to un-inoculated control under drought stress. The present study also showed that the synergy of PGPB strains (MN-54, Enterobacter, P. fluorescens 1) induced a significantly higher increase in the leaf RWC than the inoculation of individual strains (Table 3). It may be inferred that the associative symbiosis among the functionally related bacterial strains improved the soil water retention capacity (Mahmoudi et al. 2019) that ultimately increased the leaf RWC in the drought-stressed seedlings. Recently, Chaín et al. (2020) also reported a substantial enhancement in the leaf RWC of Eucalyptus grandis seedlings inoculated with bacterial consortia that might be attributed to increase in root length and diameter for water and nutrient absorption in dry soils.

The detrimental effects of drought on the photosynthetic pigments were evident by the decrease in leaf $\mathrm{Chl}_{\mathrm{a}}, \mathrm{Chl}_{\mathrm{b}}$, and CAR content of un-inoculated maize seedlings (Suppl. Table 3). The water-deficit stress damages membrane systems, disturbs mesophyll cell ultrastructure, and degrades starch granules in the chloroplasts (Shao et al. 2016). The maize seedlings inoculated with the tolerant bacterial strains exhibited less damage to the photosynthetic pigments than the inoculation of sensitive strains and control treatment (no inoculation). The highest increase in the chlorophyll and CAT content of drought stressed seedlings was observed by inoculation with Bacillus spp. (Y5, Y14, Y16, and MN-54), closely followed by Enterobacter and P. fluorescens (Suppl. Table 3). Similarly, Hashem et al. (2015) observed a significant increase in $\mathrm{Chl}_{\mathrm{a}}, \mathrm{Chl}_{\mathrm{b}}$, and CAT content of salt-stressed Bassia indica seedlings inoculated with Bacillus spp. It seems that the tolerant PGPB helped to maintain water balance by altering the root system architecture and regulating the concentration of plant nutrients and phytohormones, thereby facilitating the presence of a healthy photosynthetic system in the inoculated seedlings (Khan et al. 2019). Earlier, Armada et al. (2014) showed that the inoculation of drought stressed plants with Bacillus spp. increases the uptake of nutrients such as magnesium $\left(\mathrm{Mg}^{2+}\right)$ and calcium $\left(\mathrm{Ca}^{2+}\right)$ that regulate the homeostasis of ions and stabilize membrane systems in chloroplasts (Huda et al. 2013). Similar to our findings in maize, the inoculation of wheat with Enterobacter sp. and P. fluorescens has been previously reported to increase $\mathrm{Chl}_{\mathrm{a}}$ and $\mathrm{Chl}_{\mathrm{b}}$ content under salinity (Singh and Jha 2016) and drought stress (Jamil et al. 2018), respectively. In comparison with individual inoculation of strains, bacterial consortia treatments, i.e., MN54+ P. fluorescens 1 (T4), $\mathrm{MN}-54+$ Enterobacter (T5), P. fluorescens $1+$ Enterobacter (T6), and MN54 + P. fluorescens $1+$ Enterobacter (T7) resulted in higher $\mathrm{Chl}_{\mathrm{a}}, \mathrm{Chl}_{\mathrm{b}}$, and CAR content in waterstressed maize seedlings (Table 2). These observations are in accordance with the previous report of Aghai et al. (2019) about the beneficial effects of bacterial consortium on the mechanisms of chlorophyll production and the function of photosystem II (PSII) in Pseudotsuga menziesii and Thuja plicata during moisture deficit. The observed increment in photosynthetic pigments by bacterial consortia treatments could be attributed to increased water and nutrient availability as well as EPS production and phosphate solubilization traits of strains (Kang et al. 2017; Joshi et al. 2020), which were further enhanced by the combined application of these inoculants.

The accumulation of greater amounts of phyotosynthetic pigments by inoculated plants also contributed to the 
improvement in photosynthesis under water-deficit conditions (Suppl. Table 4). The presence of high amount of chlorophyll and carotenoids in the PGPB-inoculated plants enhances the biochemical rate of $\mathrm{CO}_{2}$ fixation, thereby improving the photosynthetic efficiency of plants under drought stress (Abdelaal et al. 2021). The photosynthetic performance of a plant is determined mainly by the leaf gas exchange characteristics that are associated with stomatal regulation, photosynthesis, and transpiration (Shehzad et al. 2020). Drought stress inhibits the leaf $A$ through reduced $g_{s}$ and $C_{i}$ that ultimately reduces the photosynthesis, also observed in the present study (Suppl. Table 4). The drought-tolerant hybrid NK-6654 exhibited lower reduction in photosynthetic characteristics than sensitive SD-626 that might be attributed to the maintenance of higher leaf water status and photosynthetic pigments under water limitations. The bacterial inoculation augmented the adaptive ability of NK-6654, resulting in higher $A, g_{s}$, and $C_{i}$ in the seedlings inoculated with tolerant strains, i.e., MN-54, Enterobacter, and P. fluorescens 1, as compared to no inoculation (control) or the inoculation of sensitive strains under drought stress. This improved photosynthetic performance might be associated to the production of high root biomass in maize seedlings inoculated with tolerant strains (Suppl. Table 3) that contributed to increased absorption of water and mineral ions to stimulate photosynthesis under water-deficit conditions. A recent study by Afzal et al. (2020) also demonstrated that the inoculation of maize with Bacillus sp. MN-54 led to significant increases in the gas exchange characteristics that were linked to the maintenance of chlorophyll and increased stomatal control. Barnawal et al. (2013) reported that the treatment with Bacillus spp. increases the uptake of macronutrients and modulates ion homeostasis to enhance photosynthesis in plants under dry conditions. Moreover, the regulation of high affinity potassium transporters (HKT) by these bacteria plays a key role in controlling the stomatal opening, osmotic balance, and transpiration losses in drought-stressed plants (Loutfy et al. 2012). In the present study, the treatment with the drought tolerant strains gave the lowest $E$ in maize seedlings suggesting the adjustment of stomatal apparatus to prevent water loss, and thereby reducing the damage to photosynthetic tissues ( $\mathrm{Li}$ et al. 2017). These observations agree with the previous report of Castillo et al. (2013) who showed that the bacterial inoculation of sunflower seedlings could significantly decrease water loss by transpiration, probably due to increased ABA synthesis to induce stomatal closure under water-deficit conditions. The decrease in $E$ and an improved activity of $A$, $g s$, and $\mathrm{Ci}$ by the consortium treatments (Table 3 ) indicates the beneficial associations among the bacterial inoculants to induce drought tolerance in maize. It is believed that these synergistic interactions affect photosynthetic characteristics by improving the availability of water, and regulating the nutritional and hormonal balance in water-stressed plants (Shabbir et al. 2019). Radhakrishnan et al. (2017) suggested that the co-inoculation of Bacillus spp. with a compatible strain confers benefits to the photosynthetic apparatus by stimulating the synthesis of pigments and enhancing the activity of antioxidant enzymes under limited moisture conditions.

Drought-mediated disturbance of normal physiological processes results in the generation of ROS, which affect biological membranes to induce lipid peroxidation and cause electrolyte leakage in drought-exposed plants (Miller et al. 2010). The treatment of maize plants with bacterial inoculants stimulated the overall physiological activities of cells such as the maintenance of high leaf RWC, pigments, and a better performance of photosynthetic apparatus which contributed to less ROS-induced damages as compared to no inoculation. The PGPB inoculation has been well reported to stimulate defense mechanisms such as the activation of low molecular weight antioxidant enzymes to scavenge ROS in water stressed plants (Vaishnav et al. 2020; Moreno-Galván et al. 2020). In the present study, a marked increment in the activities of CAT, GPX, and SOD was also observed by the inoculation of maize seedlings with drought-tolerant bacterial strains (Suppl. Table 4). The SOD is a key antioxidant enzyme that catalyzes the breakdown of toxic superoxide radicals to $\mathrm{H}_{2} \mathrm{O}_{2}$, which is further broken down into molecular oxygen $\left(\mathrm{O}_{2}\right)$ or water by CAT (Dumanović et al. 2020). We found that the modulation of antioxidant defense is strainspecific as the maize seedlings treated Bacillus sp. Y14 and B. subtilis exhibited low antioxidant activity, whereas other Bacillus spp. (MN-54 and B. cereus Y5) resulted in high CAT, SOD, and GPX activities in water-stressed maize seedlings. This may suggest that the upregulation of antioxidant enzymes in specific tolerant strains helped to minimize drought-induced oxidative damage, evident by the production of high biomass (Suppl. Table 3) and the maintenance of higher photosynthetic activity (Suppl. Table 4) than un-inoculated control under drought stress. Moreover, the maize seedlings inoculated with Enterobacter sp. exhibited significantly higher antioxidant activity than uninoculated control, also reported by Maqbool et al. (2021). The enhanced expression of ROS-scavenging antioxidant enzymes in PGPB-inoculated plants could be associated to the ability of bacterial inoculants to exhibit increased ACCdeaminase activity, siderophore production, and phosphate solubilization under adverse conditions (Gururani et al. 2013). Radhakrishnan et al. (2017) suggested that the inoculation of plants with tolerant strains helps to modulate osmotic balance and photosynthetic activity to mitigate ROS-induced drought injury. These effects of Bacillus spp. on the enzymatic activities are further corroborated by the reports of Narayanasamy et al. (2020) in rice. Moreover, a considerable enhancement in CAT, GPX, and SOD activities was recorded by the consortium treatments (T4-T7) as compared to single bacterial inoculants T1, T2, and T3. Besides, the observed increments in the GPX and SOD activities were significantly 
higher in drought tolerant (NK-6654) than sensitive (SD-626) maize hybrid (Table 4). Anjum et al. (2017) suggested that significantly higher expression of antioxidant enzymes in drought tolerant than sensitive maize hybrids could be used as an effective stress indicator. Our results showed that the synergistic relationships among resistant bacterial inoculants could further enhance the activity of tolerance mechanisms to alleviate the drastic effects of drought in maize. Similarly, the inoculation of cucumber with a consortium of Bacillus spp. was reported to enhance the SOD and photosynthetic activity under water-deficit conditions (Wang et al. 2012).

\section{Conclusions}

In conclusion, our results indicate that the bacterial strains vary in their response to drought stress, and the use of tolerant inoculants could be a viable, effective strategy to improve maize growth under water-deficit conditions. The high drought tolerance of maize plants inoculated with Bacillus sp. MN-54, Enterobacter sp. FD-17, and Pseudomonas fluorescens 1 was found associated to the maintenance of leaf water status that resulted in greater amounts of photosynthetic pigments, thereby increasing photosynthetic activity and higher accumulation of biomass than uninoculated control. Also, the treatment of maize seedlings with bacterial consortia was found more beneficial than the inoculation of individual strains to increase early growth under water limitations. This work advances the importance of drought-tolerant bacterial strains and their consortia and demonstrated how synergistic bacterial interactions could be exploited for the development of an affordable biofertilizer for farmers in harsh dry regions. Hence, field trials aimed at understanding the potential use of indigenous biofertilizers for applications in dry land agricultural systems are suggested for future studies.

Supplementary Information The online version contains supplementary material available at https://doi.org/10.1007/s42729-021-00620-y.

Acknowledgements The present study was carried out as a part of doctoral thesis of Mr. Muhammad Saleem, PhD scholar at MNS University of Agriculture, Multan, Pakistan. The authors are grateful to the Institute of Soil and Environmental Sciences, University of Agriculture, Faisalabad, Pakistan, for providing the biomaterial for this study. We highly appreciate the critical reading of manuscript by Dr. Xuejun Dong, Associate Professor of Crop Physiology at Texas A\&M AgriLife Research and Extension Center, Uvalde (USA), that helped to remove any grammatical, typing errors and considerably improved the language quality of this manuscript.

Author Contribution FN and MBH envisaged and designed the experiments, MS performed all the experimental work including the laboratory analyses, and RMI provided support for the experimental work including reagents. FN and MS wrote the manuscript. FN performed language editing and critical reading of the manuscript.
Funding Open Access funding enabled and organized by Projekt DEAL. The financial support as a postdoctoral fellowship to Dr. Fahim Nawaz by Alexander von Humboldt ( $\mathrm{AvH})$ Foundation, Germany, is gratefully acknowledged.

\section{Declarations}

Competing interest The authors declare no competing interests.

Open Access This article is licensed under a Creative Commons Attribution 4.0 International License, which permits use, sharing, adaptation, distribution and reproduction in any medium or format, as long as you give appropriate credit to the original author(s) and the source, provide a link to the Creative Commons licence, and indicate if changes were made. The images or other third party material in this article are included in the article's Creative Commons licence, unless indicated otherwise in a credit line to the material. If material is not included in the article's Creative Commons licence and your intended use is not permitted by statutory regulation or exceeds the permitted use, you will need to obtain permission directly from the copyright holder. To view a copy of this licence, visit http://creativecommons.org/licenses/by/4.0/.

\section{References}

Abdelaal K, AlKahtani M, Attia K, Hafez Y, Király L, Künstler A. The role of plant growth-promoting bacteria in alleviating the adverse effects of drought on plants. Biology. 10:520. 10.3390/ biology 10060520

Aebi H (1984) Catalase in vitro. Methods Enzymol 105:121-126. 10. 1016/ S0076- 6879(84) 05016-3.

Afzal MJ, Khan MI, Cheema SA, Hussain S, Anwar-ul-Haq M, Ali MH, Naveed M (2020) Combined application of Bacillus sp. $\mathrm{MN}-54$ and phosphorus improved growth and reduced lead uptake by maize in the lead-contaminated soil. Environ Sci Pollut Res 27:44528-44539. https://doi.org/10.1007/s11356-020-10372-4

Aghai MM, Khan Z, Joseph MR, Stoda AM, Sher AW, Ettl GJ, Doty SL (2019) The effect of microbial endophyte consortia on Pseudotsuga menziesii and Thuja plicata survival, growth, and physiology across edaphic gradients. Front Microbiol 10:1353. https://doi.org/ 10.3389/fmicb.2019.01353

Anjum SA, Ashraf U, Tanveer M, Khan I, Hussain S, Shahzad B, Zohaib A, Abbas F, Saleem MF, Ali I, Wang LC (2017) Drought induced changes in growth, osmolyte accumulation and antioxidant metabolism of three maize hybrids. Front Plant Sci 8:69. https:// doi.org/10.3389/fpls.2017.00069

Ansari FA, Jabeen M, Ahmad I (2021) Pseudomonas azotoformans FAP5, a novel biofilm-forming PGPR strain, alleviates drought stress in wheat plant. Int J Environ Sci Technol. https://doi.org/10. 1007/s13762-020-03045-9

Araujo FF, Bonifacio A, Bavaresco LG, Mendes LW, Araujo ASF (2021) Bacillus subtilis changes the root architecture of soybean grown on nutrient-poor substrate. Rhizosphere 18:100348. https:// doi.org/10.1016/j.rhisph.2021.100348

Armada E, Roldán A, Azcon R (2014) Differential activity of autochthonous bacteria in controlling drought stress in native Lavandula and Salvia plants species under drought conditions in natural arid soil. Microbial Ecol 67:410-420. https://doi.org/10.1007/ s00248-013-0326-9

Armada E, Barea JM, Castillo P, Roldán A, Azcón R (2015) Characterization and management of autochthonous bacterial strains from semiarid soils of Spain and their interactions with fermented 
agrowastes to improve drought tolerance in native shrub species. Appl Soil Ecol 96:306-318. https://doi.org/10.1016/j.apsoil.2015. 08.008

Arnon DI (1949) Copper enzymes in isolated chloroplasts. Polyphenoloxidase in Beta Vulgaris Plant Physiol 24:1-15. https://doi.org/ 10.1104/pp.24.1.1

Barnawal D, Maji D, Bharti N, Chanotiya CS, Kalra A (2013) ACC deaminase-containing Bacillus subtilis reduces stress ethyleneinduced damage and improves mycorrhizal colonization and rhizobial nodulation in Trigonella foenum-graecum under drought stress. J Plant Growth Reg 32:809-822. https://doi.org/10.1007/ s00344-013-9347-3

Berg G, Rybakova D, Fischer D, Cernava T, Vergès MCC, Charles T, Chen X, Cocolin L, Eversole K, Corral GH et al (2020) Microbiome definition re-visited: old concepts and new challenges. Microbiome 8:103. https://doi.org/10.1186/s40168-020-00875-0

Buono D (2020) Can biostimulants be used to mitigate the effect of anthropogenic climate change on agriculture? It is time to respond. Sci Total Environ 751:141763. https://doi.org/10.1016/j.scitotenv. 2020.141763

Busse MD, Bottomley PJ (1989) Growth and nodulation responses of Rhizobium meliloti to water stress induced by permeating and non-permeating solutes. Appl Environ Microbiol 55:2431-2436. https://doi.org/10.1128/aem.55.10.2431-2436.1989

Canales FJ, Nagel KA, Müller C, Rispail N, Prats E (2019) Deciphering root architectural traits involved to cope with water deficit in Oat. Front Plant Sci 10:1558. https://doi.org/10.3389/fpls.2019.01558

Castillo P, Escalante M, Gallardo M, Alemano S, Abdala G (2013) Effects of bacterial single inoculation and co-inoculation on growth and phytohormone production of sunflower seedlings under water stress. Acta Physiol Plant 35:2299-2309. https://doi.org/10.1007/ s11738-013-1267-0

Chaín JM, Tubert E, Graciano C, Castagno LN, Recchi M, Pieckenstain FL, Estrella MJ, Gudesblat G, Amodeo G, Baroli I (2020) Growth promotion and protection from drought in Eucalyptus grandis seedlings inoculated with beneficial bacteria embedded in a superabsorbent polymer. Sci Rep 10:18221. https://doi.org/ 10.1038/s41598-020-75212-4

Daryanto S, Wang L, Jacinthe PA (2016) Global synthesis of drought effects on maize and wheat production. PLoS ONE 11:e0156362. https://doi.org/10.1371/journal.pone.0156362

Davies B (1976) Carotenoids. In: Chemistry and Biochemistry of Plant Pigments, ed.T.W.Goodwin (London: Academic Press), pp. $38-165$.

Deryng D, Conway D, Ramankutty N, Price J, Warren R (2014) Global crop yield response to extreme heat stress under multiple climate change futures. Environ Res Lett 9:034011. https://doi.org/10. 1088/1748-9326/9/4/041001

Drogue B, Dore H, Borland S, Wisniewski-Dye F, Prigent-Combaret C (2012) Which specificity in cooperation between phytostimulating rhizobacteria and plants? Res Microbiol 163:500-510. https://doi. org/10.1016/j.resmic.2012.08.006

Dumanović J, Nepovimova E, Natić M, Kuča K, Jaćević V (2020) The significance of reactive oxygen species and antioxidant defense system in plants: a concise overview. Front Plant Sci 11:552969. https://doi.org/10.3389/fpls.2020.552969

García JE, Maroniche G, Creus C, Suárez-Rodríguez R, Ramirez-Trujillo JA, Groppa MD (2017) In vitro PGPR properties and osmotic tolerance of different Azospirillum native strains and their effects on growth of maize under drought stress. Microbiol Res 202:2129. https://doi.org/10.1016/j.micres.2017.04.007

Gouda S, Kerry RG, Das G, Paramithiotis S, Shin HS, Patra JK (2018) Revitalization of plant growth promoting rhizobacteria for sustainable development in agriculture. Microbiol Res 206:131-140. https://doi.org/10.1016/j.micres.2017.08.016
Gururani MA, Upadhyaya CP, Baskar V, Venkatesh J, Nookaraju A, Park SW (2013) Plant growth-promoting rhizobacteria enhance abiotic stress tolerance in Solanum tuberosum through inducing changes in the expression of ROS-scavenging enzymes and improved photosynthetic performance. J Plant Growth Reg 32:245-258. https://doi.org/10.1007/s00344-012-9292-6

Hashem A, Abd-Allah EF, Alqarawi AA, Al-Huqail AA, Alshalawi SRM, Wirth S, Egamberdieva D (2015) Salt tolerant PGPR Bacillus subtilis improved growth and physiological parameters of Indian bassia (Bassia indica) under salt stress condition. Pak J Bot 47:1735-1741

Hsieh TF, Huang HC, Erickson RS (2010) Spread of seed-borne Erwinia rhapontici in bean, pea and wheat. Eur J Plant Pathol 127:579-584. https://doi.org/10.1007/s10658-010-9622-0

Huda KMK, Yadav S, Banu MSA, Trivedi DK, Tuteja N (2013) Genome-wide analysis of plant-type II $\mathrm{Ca}^{2+}$ ATPases gene family from rice and Arabidopsis: potential role in abiotic stresses. Plant Physiol Biochem 65:32-47. https://doi.org/10.1016/j.plaphy.2013. 01.002

Imran M, Iqbal M, Ullah E (2014) Assessing yield, water use efficiency and evapotranspiration with ameliorating effect of potassium in wheat crop exposed to regulated deficit irrigation. Pak J Nutr 13:168-175. https://doi.org/10.3923/pjn.2014.168.175

Jamil M, Ahamd M, Anwar F, Zahir ZA, Kharal MA, Nazli F (2018) Inducing drought tolerance in wheat through combined use of 1-tryptophan and Pseudomonas fluorescens. Pak J Agric Sci 55:331-337. https://doi.org/10.21162/PAKJAS/18.4980

Jochum MD, McWilliams KL, Borrego EJ, Kolomiets MV, Niu G, Pierson EA, Jo YK (2019) Bioprospecting plant growth-promoting rhizobacteria that mitigate drought stress in grasses. Front Microbiol 10:2106. https://doi.org/10.3389/fmicb.2019.02106

Joshi B, Chaudhary A, Singh H, Kumar PA (2020) Prospective evaluation of individual and consortia plant growth promoting rhizobacteria for drought stress amelioration in rice (Oryza sativa L.). Plant Soil 457:225-240. https://doi.org/10.1007/s11104-020-04730-x

Kang SM, Radhakrishnan R, You YH, Khan AL, Lee KE, Lee JD et al (2015) Enterobacter asburiae KE17 association regulates physiological changes and mitigates the toxic effects of heavy metals in soybean. Plant Biol 17:1013-1022. https://doi.org/10.1111/plb. 12341

Karim MR, Rahman MA (2015) Drought risk management for increased cereal production in Asian least developed countries. Weather Climate Extrem 7:24-35. https://doi.org/10.1016/j.wace.2014.10.004

Kasim W, Osman M, Omar M, Abd El-Daim I, Bejai S, Meijer J (2013) Control of drought stress in wheat using plant-growth promoting rhizobacteria. J Plant Growth Regul 32:122-130. https://doi.org/ 10.1007/s00344-012-9283-7

Kavadia A, Omirou M, Fasoula D, Ioannides IM (2020) The importance of microbial inoculants in a climate-changing agriculture in eastern Mediterranean region. Atmosphere 11:1136. https://doi.org/ 10.3390/atmos 11101136

Khan MY, Zahir ZA, Asghar HN, Waraich EA (2017) Preliminary investigations on selection of synergistic halotolerant plant growth promoting rhizobacteria for inducing salinity tolerance in wheat. Pak J Bot 49:1541-1551

Khan N, Bano A, Zandi P (2018) Effects of exogenously applied plant growth regulators in combination with PGPR on the physiology and root growth of chickpea (Cicer arietinum) and their role in drought tolerance. J Plant Interact 13:239-247. https://doi.org/10. 1080/17429145.2018.1471527

Khan N, Bano A (2019) Exopolysaccharide producing rhizobacteria and their impact on growth and drought tolerance of wheat grown under rainfed conditions. PLoS ONE 14:e0222302. https://doi.org/ 10.1371/journal.pone.0222302 
Kumar A, Verma JP (2018) Does plant-microbe interaction confer stress tolerance in plants: a review? Microbiol Res 207:41-52. https://doi.org/10.1016/j.micres.2017.11.004

Leng G (2021) Maize yield loss risk under droughts in observations and crop models in the United States. Environ Res Lett 16:024016. https://doi.org/10.1088/1748-9326/abd500

Lesk C, Rowhani P, Ramankutty N (2016) Influence of extreme weather disasters on global crop production. Nature 529:84-87. https://doi. org/10.1038/nature16467

Li C, Wang Z, Nong Q, Lin L, Xie J, Mo Z, Huang X, Song X, Malviya MK, Solanki MK, Li Y (2021) Physiological changes and transcriptome profiling in Saccharum spontaneum L. leaf under water stress and re-watering conditions. Sci Rep 11:5525. https://doi.org/ 10.1038/s41598-021-85072-1

Li Y, Li H, Li Y, Zhang S (2017) Improving water-use efficiency by decreasing stomatal conductance and transpiration rate to maintain higher ear photosynthetic rate in drought-resistant wheat. The Crop J 5:231-239. https://doi.org/10.1016/j.cj.2017.01.001

Lin W, Li Y, Du S, Zheng Y, Gao J, Sun T (2019) Effect of dust deposition on spectrum-based estimation of leaf water content in urban plant. Ecol Indic 104:41-47. https://doi.org/10.1016/j.ecolind. 2019.04.074

Loutfy N, El-Tayeb MA, Hassanen AM, Moustafa MFM, Sakuma Y, Inouhe M (2012) Changes in the water status and osmotic solute contents in response to drought and salicylic acid treatments in four different cultivars of wheat (Triticum aestivum). J Plant Res 125:173-184. https://doi.org/10.1007/s10265-011-0419-9

Luhunga PM (2017) Assessment of the impacts of climate change on maize production in the Southern and Western Highlands Sub-agro Ecological Zones of Tanzania. Front Environ Sci 5:51. https://doi. org/10.3389/fenvs.2017.00051

Lyngwi NA, Joshi SR (2014) Economically important Bacillus and related genera: a mini review. Bio Useful Plants Microbes 3:33-43. https://doi.org/10.12691/jaem-8-2-1

Madadgar S, Aghakouchak A, Farahmand A, Davis SJ (2017) Probabilistic estimates of drought impacts on agricultural production. Geophys Res Lett 44:7799-7807. https://doi.org/10.1002/2017G L073606

Mahmoudi TR, Yu JM, Liu S, Pierson LS III, Pierson EA (2019) Drought-stress tolerance in wheat seedlings conferred by phenazine-producing rhizobacteria. Front Microbiol 10:1590. https:// doi.org/10.3389/fmicb.2019.01590

Majeed S, Nawaz F, Naeem M, Ashraf MY (2018) Effect of exogenous nitric oxide on sulfur and nitrate assimilation pathway enzymes in maize (Zea mays L.) under drought stress. Acta Physiol Plant 40: 206. https://doi.org/10.1007/s11738-018-2780-y

Majeed S, Nawaz F, NaeemM AMY, Ejaz S, Ahmad KS, Tauseef S, Farid G, Khalid I, Mehmood K (2020) Nitric oxide regulates water status and associated enzymatic pathways to inhibit nutrients imbalance in maize (Zea mays L.) under drought stress. Plant Physiol Biochem 155:147-160. https://doi.org/10.1016/j.plaphy. 2020.07.005

Maqbool S, Amna A, Mehmood S, Suhaib M, Sultan T, Munis MFH (2021) Interaction of ACC deaminase and antioxidant enzymes to induce drought tolerance in Enterobacter cloacae 2WC2 inoculated maize genotypes. Pak J Bot 53:508. https://doi.org/10.30848/ PJB2021-3(28)

Miller GAD, Suzuki N, Ciftci-Yilmaz S, Mittler R (2010) Reactive oxygen species homeostasis and signalling during drought and salinity stresses. Plant Cell Environ 33:453-467. https://doi.org/10.1111/j. 1365-3040.2009.02041.x

Molina-Romero D, Juárez-Sánchez S, Venegas B, Ortíz-González CS, Baez A, Morales-García YE, Muñoz-Rojas J (2021) A bacterial consortium interacts with different varieties of maize, promotes the plant growth, and reduces the application of chemical fertilizer under field conditions. Front Sustain Food Syst 4:293. https://doi. org/10.3389/fsufs.2020.616757

Moreno-Galván A, Romero-Perdomo FA, Estrada-Bonilla G, Meneses CHSG, Bonilla RR (2020) Dry-caribbean Bacillus spp. strains ameliorate drought stress in maize by a strain-specific antioxidant response modulation. Microorganisms 8:823 https://doi.org/10. 3390/microorganisms 8060823

Mpanga IK, Gomez-Genao N, Moradtalab N, Wanke D, Chrobaczek V, Ahmed A, Windisch S, Geistlinger J, Hafiz FB, Walker F, Ludewig $\mathrm{U}$ (2019) The role of $\mathrm{N}$ form supply for PGPM-host plant interactions in maize. J Plant Nutr Soil Sci 182:908-920. https://doi.org/ 10.1002/jpln.201900133

Nadeem SM, Zahir ZA, Naveed M, Arshad M (2007) Preliminary investigations on inducing salt tolerance in maize through inoculation with rhizobacteria containing ACC deaminase activity. Canadian J Microbiol 53:1141-1149. https://doi.org/10.1139/W07-081

Nadeem SM, Zahir ZA, Naveed M, Ashraf M (2010) Microbial ACCdeaminase: prospects and applications for inducing salt tolerance in plants. Critic Rev Plant Sci 29:360-393. https://doi.org/10.1080/ 07352689.2010 .524518

Naeem M, Naeem MS, Ahmad R, Ihsan MZ, Ashraf MY, Hussain Y, Fahad S (2018) Foliar calcium spray confers drought stress tolerance in maize via modulation of plant growth, water relations, proline content and hydrogen peroxide activity. Arch Agron Soil Sci 64:116-131. https://doi.org/10.1080/03650340.2017.1327713

Narayanasamy S, Thangappan S, Uthandi S (2020) Plant growthpromoting bacillus sp. cahoots moisture stress alleviation in rice genotypes by triggering antioxidant defense system. Microbiol Res 239:126518. https://doi.org/10.1016/j.micres.2020.126518

Naveed M, Mitter B, Reichenauer TG, Wieczorek K, Sessitsch A (2014) Increased drought stress resilience of maize through endophytic colonization by Burkholderia phytofirmans PsJN and Enterobacter sp. FD17. Environ Exp Bot 97:30-39. https://doi.org/10.1016/j. envexpbot.2013.09.014

Niu X, Song L, Xiao Y, Ge W (2018) Drought-tolerant plant growthpromoting rhizobacteria associated with foxtail millet in a semiarid agroecosystem and their potential in alleviating drought stress. Front Microbiol 8:2580. https://doi.org/10.3389/fmicb.2017.02580

Pereira S, Singh RS, Oliveira L, Ferreira E, Rosa E, Marques G (2020) Co-inoculation with rhizobia and mycorrhizal fungi increases yield and crude protein content of cowpea (Vigna unguiculata (L.) Walp.) under drought stress. Landbauforschung J Sust Org Agric Syst 70:56-65. https://doi.org/10.3220/LBF1607613362000

Radhakrishnan R, Hashem A, AbdAllah EF (2017) Bacillus: a biological tool for crop improvement through bio-molecular changes in adverse environments. Front Physiol 8:667. https://doi.org/10. 3389/fphys.2017.00667

Rubin RL, van Groenigen KJ, Hungate BA (2017) Plant growth promoting rhizobacteria are more effective under drought: a meta-analysis. Plant Soil 416:309-323. https://doi.org/10.1007/ s11104-017-3199-8

Samreen T, Zahir ZA, Naveed M, Asghar M (2019) Boron tolerant phosphorus solubilizing Bacillus spp MN-54 improved canola growth in alkaline calcareous soils. Int J Agric Biol 21:538-546. https://doi.org/10.17957/IJAB/15.0926

Sandhya VZAS, Grover M, Reddy G, Venkateswarlu B (2009) Alleviation of drought stress effects in sunflower seedlings by the exopolysaccharides producing Pseudomonas putida strain GAP-P45. Biol Fert Soils 46:17-26. https://doi.org/10.1007/s00374-009-0401-z

Shabbir RN, Ali H, Nawaz F, Hussain S, Areeb A, Sarwar N, Ahmad S (2019) Use of biofertilizers for sustainable crop production. In: Agronomic Crops, Springer, Singapore, pp. 149-162. https://doi. org/10.1007/978-981-32-9783-8_9

Shahzad S, Khan MY, Zahir ZA, Asghar HN, Chaudhry UK (2017) Comparative effectiveness of different carriers to improve the 
efficacy of bacterial consortium for enhancing wheat production under salt affected field conditions. Pak J Bot 49:1523-1530

Shao RX, Xin LF, Zheng HF, Li LL, Ran WL, Mao J, Yang QH (2016) Changes in chloroplast ultrastructure in leaves of drought-stressed maize inbred lines. Photosynthetica 54:74-80. https://doi.org/10. 1007/s11099-015-0158-6

Shehzad MA, Nawaz F, Ahmad F, Ahmad N, Masood S (2020) Protective effect of potassium and chitosan supply on growth physiological processes and antioxidative machinery in sunflower Helianthus annuus L under drought stress. Ecotox Environ Saf 187:109841. https://doi.org/10.1016/j.ecoenv.2019.109841

Singh RP, Jha PN (2016) Mitigation of salt stress in wheat plant (Triticum aestivum) by ACC deaminase bacterium Enterobacter sp SBP-6 isolated from Sorghum bicolor. Acta Physiol Plant. 38:110

Tebaldi C, Lobell D (2018) Estimated impacts of emission reductions on wheat and maize crops. Clim Change 146:533-545. https://doi. org/10.1007/s10584-015-1537-5

Tigchelaar M, Battisti DS, Naylor RL, Ray DK (2018) Future warming increases probability of globally synchronized maize production shocks. Proc Nat Acad Sci 115:6644-6649. https://doi.org/10. 1073/pnas.1718031115

Ulrich DE, Sevanto S, Ryan M, Albright MB, Johansen RB, Dunbar JM (2019) Plant-microbe interactions before drought influence plant physiological responses to subsequent severe drought. Sci Rep 9:249. https://doi.org/10.1038/s41598-018-36971-3

Urbanek H, Kuzniak-Gebarowska E, Herka K (1991) Elicitation of defence responses in bean leaves by Botrytis cinerea polygalacturonase. Acta Physiol Plantar 13:43-50

Usmani MM, Nawaz F, Majeed S, Shehzad MA, Ahmad KS, Akhtar G, Aqib M, Shabbir RN (2020) Sulfate-mediated drought tolerance in maize involves regulation at physiological and biochemical levels. Sci Rep 10:1-3. https://doi.org/10.1038/s41598-020-58169-2

Van Rossum MWPC, Alberda M, van der Plas LHW (1997) Role of oxidative damage in tulip bulb scale micro propagation. Plant Sci 130:207-216. https://doi.org/10.1016/S0168-9452(97)00215-X

Vaishnav A, Singh J, Singh P, Rajput RS, Singh HB, Sarma BK (2020) Sphingobacterium sp BHU-AV3 induces salt tolerance in tomato by enhancing antioxidant activities and energy metabolism. Front Microbiol 11:443. https://doi.org/10.3389/fmicb.2020.00443
Vurukonda SSKP, Vardharajula S, Shrivastava M, Skz A (2016) Enhancement of drought stress tolerance in crops by plant growth promoting rhizobacteria. Microbiol Res 184:13-24. https://doi.org/ 10.1016/j.micres.2015.12.003

Wang CJ, Yang W, Wang C, Gu C, Niu DD, Liu HX, Wangand YP, Guo $\mathrm{JH}$ (2012) Induction of drought tolerance in cucumber plants by a consortium of three plant growth-promoting rhizobacterium strains. PLoS ONE 7:52565. https://doi.org/10.1371/journal.pone.0052565

Waśkiewicz A, Irzykowska L (2014) Flavobacterium spp.-characteristics, occurrence, and toxicity. In: Encyclopedia of Food Microbiology (Second Edition). pp. 938-942. https://doi.org/10.1016/ B978-0-12-384730-0.00126-9

Woo SL, Pepe O (2018) Microbial consortia: promising probiotics as plant biostimulants for sustainable agriculture. Front Plant Sci 9:1801. https://doi.org/10.3389/fpls.2018.01801

Yang A, Akhtar SS, Fu Q, Naveed M, Iqbal S, Roitsch T, Jacobsen SE (2020) Burkholderia Phytofirmans PsJN stimulate growth and yield of quinoa under salinity stress. Plants 9:672. https://doi.org/ 10.3390/plants9060672

Zafar-ul-Hye M, Danish S, Abbas M, Ahmad M, Munir TM (2019) ACC deaminase producing PGPR Bacillus amyloliquefaciens and Agrobacterium fabrum along with biochar improve wheat productivity under drought stress. Agronomy 9:343. https://doi.org/10. 3390/agronomy 9070343

Zampieri M, Ceglar A, Dentener F, Dosio A, Naumann G, Van Den Berg M, Toreti A (2019) When will current climate extremes affecting maize production become the norm? Earth's Future 7:113-122. https://doi.org/10.1029/2018EF000995

Zhou H, Zhou G, He Q, Zhou L, Ji Y, Lv X (2021) Capability of leaf water content and its threshold values in reflection of soil-plant water status in maize during prolonged drought. Ecol Indic 124:107395. https://doi.org/10.1016/j.ecolind.2021.107395

Zipper SC, Qiu J, Kucharik CJ (2016) Drought effects on US maize and soybean production: spatiotemporal patterns and historical changes. Environ Res Lett 11:094021. https://doi.org/10.1088/ 1748-9326/11/9/094021

Publisher's note Springer Nature remains neutral with regard to jurisdictional claims in published maps and institutional affiliations. 